Lewis, W. G., Basford, J. M., \& Walton, P. L. (1978) Biochim. Biophys. Acta 522, 551-560.

Massamiri, Y., Beljeau, M., Durand, G., Feger, J., Pays, M., \& Agneray, J. (1978) Anal. Biochem. 91, 618-625.

McMullen, B. A., Fujikawa, K., \& Kisiel, W. (1983a) Biochem. Biophys. Res. Commun. 115, 8-14.

McMullen, B. A., Fujikawa, K., Kisiel, W., Sasagawa, T., Howald, W. N., Kwa, E. Y., \& Weinstein, B. (1983b) Biochemistry 22, 2875-2884.

Mizuochi, T., Yamashita, K., Fujikawa, K., Kisiel, W., \& Kotata, A. (1979) J. Biol. Chem. 254, 6419-6425.

Mizuochi, T., Yamashita, K., Fujikawa, K., Titani, K., \& Kobata, A. (1980) J. Biol. Chem. 255, 3526-3531.

Mizuochi, T., Taniguchi, T., Fujikawa, K., Titani, T., \& Kotata, A. (1983) J. Biol. Chem. 258, 6020-6024.

Pierce, M., \& Arango, J. (1986) J. Biol. Chem. 261, 10772-10777.

Pohl, G., Källström, M., Bergsdorf, N., Wallēn, P., \& Jörnvall, H. (1984) Biochemistry 23, 3701-3707.

Radcliffe, R., \& Nemerson, Y. (1975) J. Biol. Chem. 250, 388-395.
Reinhold, V. (1972) Methods Enzymol. 25, 244-249.

Roberts, H. R., \& Zeitler, K. D. (1982) in Hemostasis and Thrombosis (Colman, R. W., Hirsh, J., Marder, V. J., \& Salzman, E. W., Eds.) pp 134-137, Lippincott, Philadelphia.

Rüegg, U. Th., \& Rudinger, J. (1974) Isr. J. Chem. 12, 391-401.

Seligsohn, U., Österud, B., Brown, S. F., Griffin, J. H., \& Rapaport, S. I. (1979) J. Clin. Invest. 64, 1056-1065.

Stenflo, J., \& Öhlin, A.-K. (1987) in Current Advances in Vitamin K Research (Suttie, J. W., Ed.) pp 109-120, Elsevier, New York.

Thim, L., Hansen, M. T., \& Soerensen, A. R. (1987) FEBS Lett. 212, 307-312.

Wakabayashi, K., Sakata, Y., \& Aoki, N. (1986) J. Biol. Chem. 261, 11097-11105.

Wion, K. L., Kelly, D., Summerfield, J. A., Tuddenham, E. G. D., \& Lawn, R. M. Nature (London) 317, 726-729.

Wright, S. F., Bourne, C. D., Hoke, R. A., Koehler, K. A., \& Hiskey, R. G. (1984) Anal. Biochem. 139, 82-90.

Yamashita, K., Ohkura, T., Tachibana, Y., Takasaki, S., \& Kobata, A. (1984) J. Biol. Chem. 259, 10834-10840.

\title{
Endogenous Phosphorylation of Basic Protein in Myelin of Varying Degrees of Compaction $^{\dagger}$
}

\author{
Patricia Schulz, ${ }^{\ddagger}$ Tony F. Cruz, ${ }^{\S}$ and Mario A. Moscarello*, \\ Research Institute, The Hospital for Sick Children. Toronto, Ontario, Canada M5G 1X8, and Department of Zoology, \\ University of Coimbra, 3000 Coimbra, Portugal \\ Received March 16, 1988; Revised Manuscript Received June 2, 1988
}

\begin{abstract}
Fractions containing myelin of varying degrees of compaction were prepared from human white matter. Protein kinase activity in these fractions was measured by using both endogenous and exogenous myelin basic protein (MBP) as substrates. In both cases, less compact myelin fractions possessed higher levels of protein kinase activity than the compact myelin fraction. In addition, the specific activity of phosphorylated basic protein was greater in the loosely compacted fractions than in compact multilamellar myelin. When basic protein in compact myelin or the myelin fractions was phosphorylated by the endogenous kinase, approximately $70 \%$ of the $\left[{ }^{32} \mathrm{P}\right]$ phosphate was incorporated at a single site, identified as Ser-102. The remaining $30 \%$ was found in three other minor sites. Electron microscopy of less compact myelin showed it was composed of fewer lamellae which correlated with a relative decrease in the proportion of cationic charge isomers (microheteromers) when MBP was subjected to gel electrophoresis at alkaline $\mathrm{pH}$. The shift in charge microheterogeneity of basic protein to the less cationic isomers in the less compact myelin fractions correlated with an increase in protein kinase activity and a greater specific activity of phosphorylated basic protein.
\end{abstract}

$\mathbf{M}$ axons, has an important role in impulse transmission. However, myelin may exist in various levels of compaction possibly reflecting different functions in various parts of the central nervous system. The isolation and characterization of several less compact myelin-containing fractions prepared from human white matter were reported recently (Cruz \& Moscarello, 1985). The myelin membranes contained in these fractions appeared to be morphologically and biochemically distinct from each other and from compact myelin. The compact

\footnotetext{
${ }^{+}$This work was supported by an operating grant from the Medical Research Council of Canada and a NATO grant for international collaboration.

$\ddagger$ The Hospital for Sick Children.

University of Coimbra.
}

myelin fraction contained the characteristic multilamellar structures whereas the denser fractions contained less compacted myelin with fewer lamellae. Similar results were obtained with myelin subfractions prepared from rodent brain (Matthieu \& Waehneldt, 1978; McIntyre et al., 1978; Pereyra \& Braun, 1983). Although the factors responsible for the differences in myelin compaction are not known, it has been suggested that charge microheterogeneity of myelin basic protein (MBP) ${ }^{1}$ may play an important role in this process (Boggs et al., 1982). The isolation of several charge isomers (components; Chou et al., 1976) of MBP has permitted us to study the effect of small changes in charge on the ability of the protein to interact with, and organize, lipid bilayers.

1 Abbreviations: MBP, myelin basic protein; SDS, sodium dodecyl sulfate; HPLC, high-performance liquid chromatography. 
In model membrane studies with lipids and MBP, the most positively charged component of basic protein (component 1 ) was shown to be $100 \%$ more effective in the formation of multilayers than component 2 (Brady et al., 1985; Moscarello et al., 1986). Thus, a difference of a single charge on basic protein such as observed between components 1 and 2 had a large effect on its ability to organize lipid vesicles into compact multilayer structures (Cheifetz \& Moscarello, 1985; Brady et al., 1985). Consistent with these results, denser myelin fractions (less compacted) were enriched in the less positively charged components (more posttranslationally modified), whereas the compact myelin fraction contained a higher proportion of the more positively charged components (less posttranslationally modified) (Cruz \& Moscarello, 1985).

Such small changes in charge microheterogeneity of basic protein have been suggested to result from posttranslational modifications such as phosphorylation, deamidation, and C-terminal arginine loss (Martenson et al., 1975; Deibler et al., 1975; Chou et al., 1976; Cheifetz \& Moscarello, 1985) although other modifications (e.g., methionine sulfoxide; Cheifetz et al., 1984) may also contribute to microheterogeneity. By extension from the model membrane studies, such alterations in the charge of basic protein in the natural membrane may affect its interactions with the lipids in a similar manner and may subsequently affect the compaction of the myelin sheath.

Phosphorylation represents a mechanism by which charge microheterogeneity can be induced in a defined and reproducible manner. Basic protein can be phosphorylated by several protein kinases both in vivo and in vitro (Miyamoto \& Kakiuchi, 1974; Sulakhe et al., 1980; Martenson et al., 1983; Turner et al., 1984; Chan et al., 1986). In model membrane studies, phosphorylation of MBP in vitro was shown to decrease the ability of MBP to (a) aggregate lipid vesicles (Cheifetz \& Moscarello, 1985), (b) organize lipid bilayers into compact, almost crystalline structures (Brady et al., 1985), and (c) increase vesicle permeability (Cheifetz et al., 1985). In an in vivo study (Desjardins \& Morell, 1983), it was demonstrated that phosphate was rapidly metabolized, presumably by some combination of protein kinase/phosphatase reactions present in myelin. Increased phosphorylation of MBP when axons are depolarized has been reported (Murray \& Steck, 1984).

Of the known mechanisms by which charge microheterogeneity can be induced, phosphorylation is the major modification known to occur in vivo. Therefore, a study of the phosphorylation of basic protein in the natural membrane system was undertaken and correlated with the degree of compaction of myelin in the different fractions. Since protein kinases represent the enzymes responsible for phosphorylation, the protein kinase activity in each of the fractions was studied also. The role that such charge microheterogeneity may play in destabilization of compact myelin structures is discussed.

\section{Materials and Methods}

Preparation of Myelin and Myelin-Containing Fractions. Myelin was prepared from human white matter as described earlier (Lowden et al., 1966). The denser myelin-containing fractions were prepared by the material pelleted in $0.88 \mathrm{M}$ sucrose as described previously (Cruz \& Moscarello, 1985). Briefly, the pelleted material was resuspended in $0.25 \mathrm{M}$ sucrose and fractionated on a discontinuous gradient consisting of $0.80 \mathrm{M}, 1.0 \mathrm{M}$, and $1.2 \mathrm{M}$ sucrose by centrifuging at $96000 \mathrm{~g}$ for $90 \mathrm{~min}$. The fractions labeled $\mathrm{P}_{3} \mathrm{~A}$ and $\mathrm{P}_{3} \mathrm{~B}$ were collected from the $0.32 / 0.80 \mathrm{M}$ and $0.80 / 1.0 \mathrm{M}$ sucrose interfaces, respectively. The membranes were washed with water and centrifuged at $100000 \mathrm{~g}$ for $30 \mathrm{~min}$. The samples were resuspended in $0.25 \mathrm{M}$ sucrose and stored at $-20^{\circ} \mathrm{C}$.

Protein Kinase Activity. Myelin and myelin-containing fractions containing $100 \mu \mathrm{g}$ of protein in total were incubated for $5 \mathrm{~min}$ at $30^{\circ} \mathrm{C}$ in $0.25 \mathrm{~mL}$ of a reaction mixture containing $10 \mathrm{mM} \mathrm{MgCl}, 10 \mu \mathrm{M}\left[\gamma-{ }^{32} \mathrm{P}\right] \mathrm{ATP}(400 \mathrm{cpm} / \mathrm{pmol})$, and 20 $\mathrm{mM}$ Tris- $\mathrm{HCl}, \mathrm{pH} 7.5$. During this time, the incorporation of [ $\left.{ }^{32} \mathrm{P}\right]$ phosphate into MBP was linear. For samples containing $\mathrm{CaCl}_{2}$, Triton $\mathrm{X}-100$, and exogenous basic protein, the final concentration of each in the reaction mixture was $10 \mu \mathrm{M}$, $0.4 \%$, and $0.4 \mathrm{mg} / \mathrm{mL}$, respectively. The reaction was terminated by the addition of $3 \mathrm{~mL}$ of cold $10 \%$ trichloroacetic acid and placed on ice. Samples were filtered and washed extensively with $10 \%$ trichloroacetic acid, and the radioactivity was determined by liquid scintillation counting.

Endogenous Phosphorylation of Basic Protein in Myelin and Myelin-Containing Fractions. Membrane samples were incubated at $30^{\circ} \mathrm{C}$ for $15 \mathrm{~min}$ in a reaction mixture containing $10 \mathrm{mM} \mathrm{MgCl}, 10 \mu \mathrm{M} \mathrm{CaCl}_{2}, 10 \mu \mathrm{M}\left[\gamma^{-32} \mathrm{P}\right] \mathrm{ATP}(400$ $\mathrm{cpm} / \mathrm{pmol}$ ), and $20 \mathrm{mM}$ Tris-HCl, $\mathrm{pH} 7.5$. For determination of total phosphate incorporated into MBP, various times of incubation were used. At each time interval, $125 \mu \mathrm{L}$ of the reaction mixture was removed and added to $1.0 \mathrm{~mL}$ of $10 \%$ trichloroacetic acid on ice. Once all of the samples were collected, the membranes were pelleted by centrifuging at $15000 \mathrm{rpm}$ for $15 \mathrm{~min}$. The supernatant was removed, and the membranes were resuspended in $100 \mu \mathrm{L}$ of sample buffer containing $62.5 \mathrm{mM}$ Tris-HCl, pH 6.8, $2 \%$ SDS, $10 \%$ glycerol, $5 \%$-mercaptoethanol, and $0.005 \%$ bromophenol blue and solubilized overnight. The solubilized membranes containing approximately $90 \mu \mathrm{g}$ of protein were run on 15\% SDS-polyacrylamide gels and stained with Coomassie blue. Bands corresponding to basic protein were cut from the gels, incubated in $1 \mathrm{~mL}$ of $25 \%$ pyridine in scintillation vials, and shaken overnight (Cruz \& Moscarello, 1985). The pyridine solution was removed for measurement of the eluted Coomassie blue dye at $595 \mathrm{~nm}$ to determine the protein concentration. The gel slice was dissolved by adding $0.2 \mathrm{~mL}$ of $\mathrm{H}_{2} \mathrm{O}_{2}$ and incubating at $60^{\circ} \mathrm{C}$ for $3 \mathrm{~h}$. Scintillant was added and radioactivity determined. The results were expressed as dpm per optical density unit at $595 \mathrm{~nm}$. The extraction of the dye by this procedure was complete and linear over the protein concentration range used in these experiments.

For extraction of phosphorylated basic protein, phosphorylation of the membrane samples under the above conditions was terminated by the addition of cold $10 \%$ trichloroacetic acid. The samples were centrifuged at $9000 \mathrm{~g}$ for $15 \mathrm{~min}$ and the pellets resuspended in $0.2 \mathrm{~N} \mathrm{H}_{2} \mathrm{SO}_{4}$. Basic protein was extracted by stirring the suspension overnight at $4{ }^{\circ} \mathrm{C}$ (Lowden et al., 1966). The acid-soluble fraction was obtained by centrifuging the suspension at $10000 \mathrm{~g}$ for $1 \mathrm{~h}$ and then dialyzing the soluble fraction extensively against $\mathrm{H}_{2} \mathrm{O}$. The solution of basic protein was lyophilized, and the basic protein was stored at $-20^{\circ} \mathrm{C}$.

Preparation of Tryptic Digests of BP. BP was digested with trypsin at an enzyme:protein ratio of $1: 50$, at $37^{\circ} \mathrm{C}$ for $24 \mathrm{~h}$ in an incubation mixture containing $0.1 \% \mathrm{NH}_{4} \mathrm{CO}_{3}$ and $2 \mathrm{mM}$ $\mathrm{CaCl}_{2}$. Digests were lyophilized and stored at $-20^{\circ} \mathrm{C}$.

Reversed-Phase HPLC. The tryptic digests of BP were fractionated by reversed-phase HPLC on a Spherasorb ODS reversed-phase column (Jones Chromatography). Peptides were eluted with a linear gradient from $0.05 \%$ trifluoroacetic acid in water to $0.05 \%$ trifluoroacetic acid in $60 \%$ acetonitrile. The flow rate was $1 \mathrm{~mL} / \mathrm{min}$ for $60 \mathrm{~min}$, and the eluant was monitored continuously at $214 \mathrm{~nm}$. The eluted peptides were 
also monitored for radioactivity by liquid scintillation counting of an aliquot of the collected fractions. The remainder was lyophilized.

High-Voltage Electrophoresis. The radioactive peptides isolated from the reversed-phase column were resuspended in $\mathrm{H}_{2} \mathrm{O}$ and spotted near the center of $20 \times 20 \mathrm{~cm}$ thin-layer cellulose plates (Kodak Eastman). Electrophoresis was carried out in a $\mathrm{pH} 4.7$ buffer containing pyridine/acetic acid/1-butanol $/ \mathrm{H}_{2} \mathrm{O}, 1: 1: 2: 36(\mathrm{v} / \mathrm{v})$ (Golds \& Braun, 1978).

After the plates were washed with acetone and $1 \%$ triethylamine in acetone, followed by $10 \%$ fluorescamine and washing with acetone (Lai, 1977), peptides were visualized under long-wave $(336 \mathrm{~nm}) \mathrm{UV}$ light. The thin-layer plates were then subjected to autoradiography to visualize the radioactive peptides by exposure to Kodak XAR film at $-70^{\circ} \mathrm{C}$ with an intensifying screen for an average of $24 \mathrm{~h}$.

Amino Acid Analyses. Amino acid analysis of radioactive peptides were performed on a Waters PICO-TAG system. The ${ }^{32} \mathrm{P}$-labeled peptides were hydrolyzed using $6 \mathrm{M} \mathrm{HCl}$ and $0.1 \%$ phenol at $110^{\circ} \mathrm{C}$ for $24 \mathrm{~h}$ in gas phase, dried, and derivatized in methanol/water/triethylamine/phenyl isothiocyanate, 7:1:1:1. Derivatized samples were analyzed by reversed-phase HPLC, and amino acids were detected at $254 \mathrm{~nm}$.

Phosphoamino Acid Analyses. Phosphopeptides were hydrolyzed in $6 \mathrm{~N} \mathrm{HCl}$ at $105^{\circ} \mathrm{C}$ under vacuum for $1.5 \mathrm{~h}$. The acid was then removed by flash evaporation with several washes of $\mathrm{H}_{2} \mathrm{O}$. The hydrolyzed peptides were spotted $4 \mathrm{~cm}$ from the end of $20 \times 20 \mathrm{~cm}$ cellulose thin-layer plates (Kodak Eastman). Phosphoserine and phosphothreonine standards (5 $\mathrm{mg}$ ) were also spotted with a trace of phenol red. Electrophoresis was carried out in formic acid/acetic acid $/ \mathrm{H}_{2} \mathrm{O}$, $1: 10: 89(\mathrm{v} / \mathrm{v}), \mathrm{pH} 1.9$ at $500 \mathrm{~V}$, until the phenol red had moved $12 \mathrm{~cm}$ (Hunganir et al., 1984). The plates were dried, developed with $1 \%$ ninhydrin in acetone to detect the phosphoamino acid standards, and then subjected to autoradiography to identify the ${ }^{32} \mathrm{P}$-labeled phosphoamino acids.

Other Methods. Samples for electron microscopy were prepared by centrifuging the membranes in $1.5-\mathrm{mL}$ Eppendorf tubes for $30 \mathrm{~min}$ at $15000 \mathrm{~g}$. The pellets were fixed overnight with $2 \%$ glutaraldehyde in $0.1 \mathrm{M}$ phosphate buffer, $\mathrm{pH} 7.2$ at $90^{\circ} \mathrm{C}$. The samples were stained with uranyl acetate and lead citrate, sectioned, and viewed in a Phillips 4000 electron microscope.

Disc gel electrophoresis at $\mathrm{pH} 10.6$ in the presence of urea was performed essentially as described by Deibler et al. (1972). Samples of $100-150 \mu \mathrm{g}$ of protein were applied to each gel and electrophoresed for $3 \mathrm{~h}$ at $3.75 \mathrm{~mA}$ per gel. The proteins were stained in $7 \%$ acetic acid containing $0.5 \%$ Amido Black.

SDS-PAGE was performed as described by Laemmli (1970), using a 15\% separating gel and 5\% stacking gel. Gels were stained with Coomassie blue.

Protein determinations were carried out by the Peterson modification of the Lowry assay (Peterson, 1977).

\section{RESULTS}

Morphology of Myelin-Containing Fractions. In a previous report, we showed that in addition to the compact myelin fraction, several other myelin-containing fractions of higher density could be isolated from human white matter. The compact myelin fraction was obtained from material banded at the $0.25 / 0.88 \mathrm{M}$ sucrose interface, whereas the denser myelin-containing fractions were obtained from material which pelleted in $0.88 \mathrm{M}$ sucrose and further fractionated on discontinuous sucrose gradients. Both the number of lamellae and the structural integrity of the multilamellar stack were highest in the myelin fraction and decreased with increasing

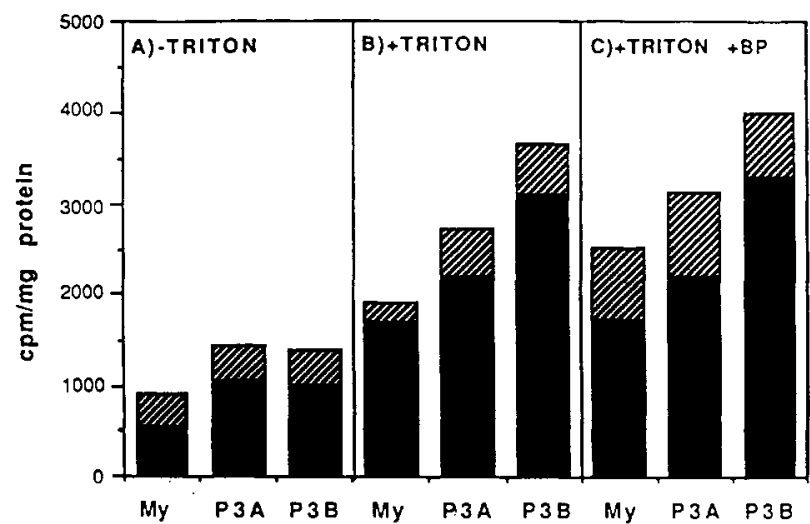

FIGURE 1: Protein kinase activity in myelin and myelin-containing fractions from human white matter. Each $250-\mu \mathrm{L}$ reaction contained myelin and myelin-containing fractions $(100 \mu \mathrm{g}$ of protein each) prepared as described under Materials and Methods, $20 \mathrm{mM}$ Tris- $\mathrm{HCl}$, $\mathrm{pH} 7.5,10 \mathrm{mM} \mathrm{MgCl}$, and $10 \mu \mathrm{M}\left[\gamma-{ }^{32} \mathrm{P}\right] \mathrm{ATP}(400 \mathrm{cpm} / \mathrm{pmol})$. Samples containing $\mathrm{CaCl}_{2}$, Triton X-100, and exogenous basic protein contained the following concentrations of each: $10 \mu \mathrm{M}, 0.4 \%$, and $0.4 \mathrm{mg} / \mathrm{mL}$, respectively. Following a $5-\mathrm{min}$ incubation at $30^{\circ} \mathrm{C}$, the reaction was terminated by the addition of $1 \mathrm{~mL}$ of cold $10 \%$ trichloroacetic acid and placed on ice. Samples were filtered and washed, and the radioactivity was determined. The results are expressed as dpm per milligram of protein. The effect of calcium on protein kinase activity is demonstrated by hatched bars.

density of the fractions (Cruz \& Moscarello, 1985).

Microheterogeneity of BP from Myelin-Containing Fractions. The relationship between the microheterogeneity of basic protein and the number of lamellae in the myelin fraction was examined by isolating basic protein from each fraction and resolving the microheteromers on polyacrylamide gel electrophoresis at alkaline $\mathrm{pH}$. Basic protein from compact myelin contained relatively more of faster moving components $(1,2$, and 3$)$ whereas the denser fractions, $P_{3} A$ and $P_{3} B$, were enriched in the less positively charged components (components 5-9) in agreement with previous results (Cruz \& Moscarello, 1985). The source of this charge microheterogeneity presumably reflected differences in the relative amounts of phosphorylation, deamidation, and C-terminal arginine loss of basic protein which occurred to variable extents in each type of myelin membrane.

Distribution of Protein Kinase Activity. The protein kinase activity was determined in myelin and myelin-containing fractions (Figure 1). In the absence of Triton X-100 (Figure $1 A$ ), no difference was observed in the specific activity of the enzyme in $\mathrm{P}_{3} \mathrm{~A}$ and $\mathrm{P}_{3} \mathrm{~B}$ although both were greater than the specific activity of the enzyme in the myelin fraction. The addition of $\mathrm{Ca}^{2+}$ to the incubation medium (hatched bars) increased the specific activity of all three fractions by approximately the same amount. In the presence of Triton X-100 (Figure 1B), the highest specific activity was observed in $\mathrm{P}_{3} \mathrm{~B}$, and the lowest was observed in the myelin fraction. The addition of $\mathrm{Ca}^{2+}$ to the incubation also increased the specific activities of $\mathrm{P}_{3} \mathrm{~A}$ and $\mathrm{P}_{3} \mathrm{~B}$ by the same increment which was between 2 and 3 times greater than the increment in the myelin fraction. The addition of exogenous basic protein (Figure 1C) did not affect the specific activity of any of the fractions, demonstrating that availability of substrate was not responsible for the differences in specific activity between the various fractions. Interestingly, the increment by which the specific activity was increased was considerably greater in the presence of $\mathrm{Ca}^{2+}$ when basic protein was added to the incubation.

Comparison of Basic Protein Phosphorylation in Myelin and Myelin-Containing Fractions. The degree of phosphorylation of basic protein in myelin and myelin-containing 

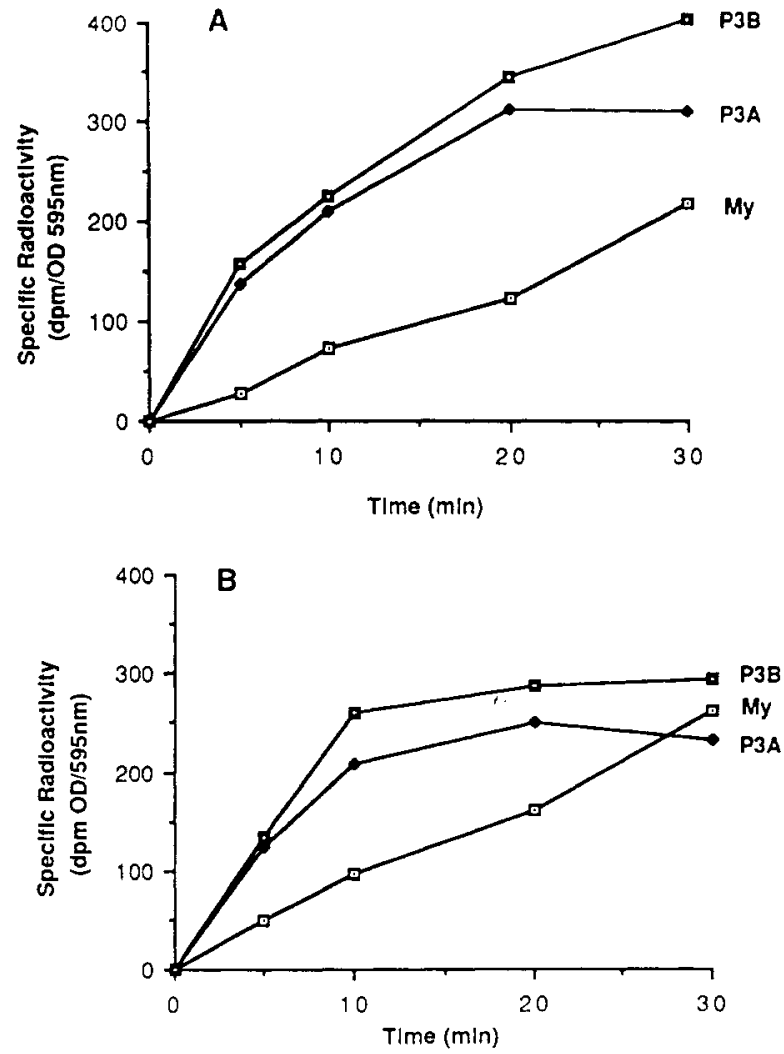

FIGURE 2: Endogenous phosphorylation of basic protein. (A) Myelin membranes were phosphorylated for different times under the conditions described under Materials and Methods. The membrane proteins were separated on $15 \%$ polyacrylamide gels and stained with Coomassie blue. Bands corresponding to basic protein were cut from the gel, and the Coomassie blue dye was removed by incubating in $1.0 \mathrm{~mL}$ of $25 \%$ pyridine overnight. From the optical density of the dye, the protein concentration was estimated (Cruz \& Moscarello, 1985). The radioactivity in each slice was determined after incubating in $0.2 \mathrm{~mL}$ of $30 \% \mathrm{H}_{2} \mathrm{O}$, for $3 \mathrm{~h}$ at $60^{\circ} \mathrm{C}$. The results are expressed as $\mathrm{dpm}$ per unit of $\mathrm{OD}_{595}$. (B) The experimental conditions were identical with above, except that $0.4 \%$ Triton X-100 was included in the phosphorylation mixture.

fractions was measured by separating phosphorylated membrane proteins on $15 \%$ polyacrylamide gels and determining the amount of ${ }^{32} \mathrm{P}$ radioactivity and Coomassie blue dye associated with basic protein bands, as described under Materials and Methods. Figure 2A shows the specific radioactivity $\left(\mathrm{dpm} / \mathrm{OD}_{595}\right)$ of phosphorylated basic protein from each membrane fraction following the indicated period of incubation. Basic protein in fractions $P_{3} A$ and $P_{3} B$ was more rapidly phosphorylated than basic protein in the myelin fraction. However, the incorporation of $\left.{ }^{32} \mathrm{P}\right]$ phosphate into basic protein continues linearly in the myelin fraction whereas a plateau is reached in fractions $P_{3} A$ and $P_{3} B$ between 20 and 30 min of incubation. After $30 \mathrm{~min}$ of incubation in the absence of detergent, the specific radioactivity of basic protein (i.e., the degree of phosphorylation) is still less in the compact myelin fraction than in $\mathrm{P}_{3} \mathrm{~A}$ or $\mathrm{P}_{3} \mathrm{~B}$.

In the presence of Triton X-100 (Figure 2B), basic protein in both $\mathrm{P}_{3} \mathrm{~A}$ and $\mathrm{P}_{3} \mathrm{~B}$ was again more rapidly phosphorylated, reaching the maximum specific radioactivity at approximately $10 \mathrm{~min}$. At $30 \mathrm{~min}$, however, the specific radioactivity of basic protein in the myelin fraction was similar to that in $\mathrm{P}_{3} \mathrm{~A}$ and $\mathrm{P}_{3} \mathrm{~B}$, probably the result of greater accessibility of MBP in the presence of Triton.

In Table I, the initial rate of phosphorylation of basic protein and the total protein kinase activity in the denser fractions, $\mathrm{P}_{3} \mathrm{~A}$ and $\mathrm{P}_{3} \mathrm{~B}$, were compared to those of the myelin fraction.
Table I: Comparison of the Rate of Phosphorylation of Basic Protein and the Relative Protein Kinase Activity in Myelin-Containing Fractions

\begin{tabular}{|c|c|c|c|}
\hline & \multicolumn{2}{|c|}{$\begin{array}{l}\text { initial rate of } \\
\text { phosphorylation }\end{array}$} & \multirow{2}{*}{$\begin{array}{l}\text { rel sp act. }{ }^{b} \text { of } \\
\text { protein kinase }\end{array}$} \\
\hline & $\overline{-T \text { Triton }}$ & +Triton & \\
\hline myelin & 360 & $636(1.8)$ & 1 \\
\hline $\mathrm{P}_{3} \mathrm{~A}$ & 1340 & $1424(1.1)$ & 1.3 \\
\hline $\mathrm{P}_{3} \mathrm{~B}$ & 1529 & $1680(1.1)$ & 1.6 \\
\hline
\end{tabular}

a Initial rate of phosphorylation of basic protein is expressed as dpm per $O_{595}$ per hour for the linear portion of each curve. The number in parentheses represents the relative increase in the rate of basic protein phosphorylation in the presence of Triton X-100. ${ }^{b}$ The relative specific activity of protein kinase was determined by dividing the specific activity in all fractions by the specific activity in the myelin fraction (from Figure 2B).

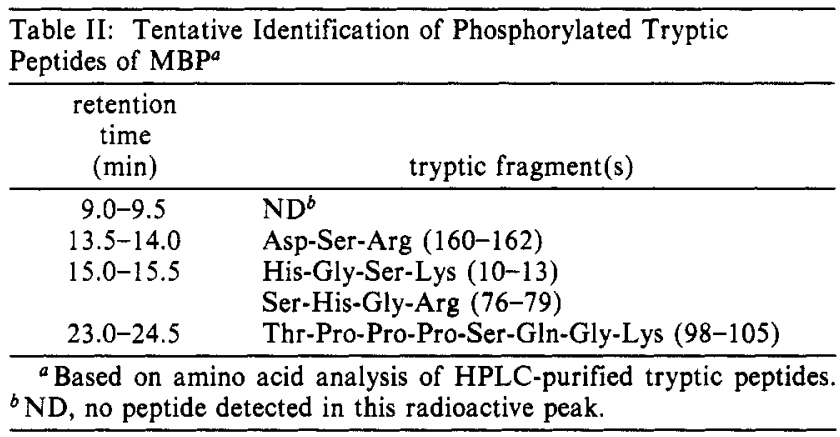

The rate of phosphorylation of basic protein in the denser fractions was higher than in the myelin fraction both in the absence and in the presence of Triton X-100. In the presence of Triton X-100, the rates of phosphorylation of basic protein increased approximately 1.8 -fold in the myelin fraction, whereas a 1.1-fold increase was observed in fractions $P_{3} A$ and $\mathrm{P}_{3} \mathrm{~B}$. In comparison, protein kinase activity was $1.3-$ and 1.6-fold higher in fractions $P_{3} A$ and $P_{3} B$ than myelin, respectively. These results would indicate that the higher rate of phosphorylation of basic protein in fractions $\mathrm{P}_{3} \mathrm{~A}$ and $\mathrm{P}_{3} \mathrm{~B}$ cannot be accounted for totally by the higher levels of protein kinase activity but that a greater accessibility of basic protein to phosphorylation exists in the less compact myelin fractions.

Identification of Phosphorylation Sites on Basic Protein. Basic protein in compact myelin was phosphorylated using $\left[{ }^{32} \mathrm{P}\right] \mathrm{ATP}$, isolated, and digested with trypsin, and the digest was fractionated by reversed-phase HPLC as described under Materials and Methods. Figure 3A shows an absorbance profile of the tryptic peptides separated by HPLC and the distribution of radioactivity (B) in the eluted fractions. One major peak containing approximately $70 \%$ of the total eluted ${ }^{32} \mathrm{P}$ was identified, as well as several minor peaks. The major peak had a retention time of 23-24.5 min, and the minor peaks had retention times of $9-9.5,13.5-14.0$, and $15.0-15.5 \mathrm{~min}$.

In order to identify the sites of phosphorylation on basic protein, aliquots of the radioactive peaks were submitted for amino acid analysis, and the remainder was further purified by high-voltage electrophoresis on thin-layer plates (see Materials and Methods). On the basis of the results of the amino acid analysis (not shown) and the known sequence of all possible tryptic peptides, the minor radioactive peptides were tentatively identified as peptides $10-13,76-79$, and 160-162 of the human sequence, and the major radioactive peak was tentatively identified as peptide $98-105$ (Table II).

Figure 4 shows the fluorescamine staining (A) and autoradiogram (B) of the major phosphorylated peak separated by electrophoresis on a thin-layer plate. Although three peptides were identified by fluorescamine staining associated 

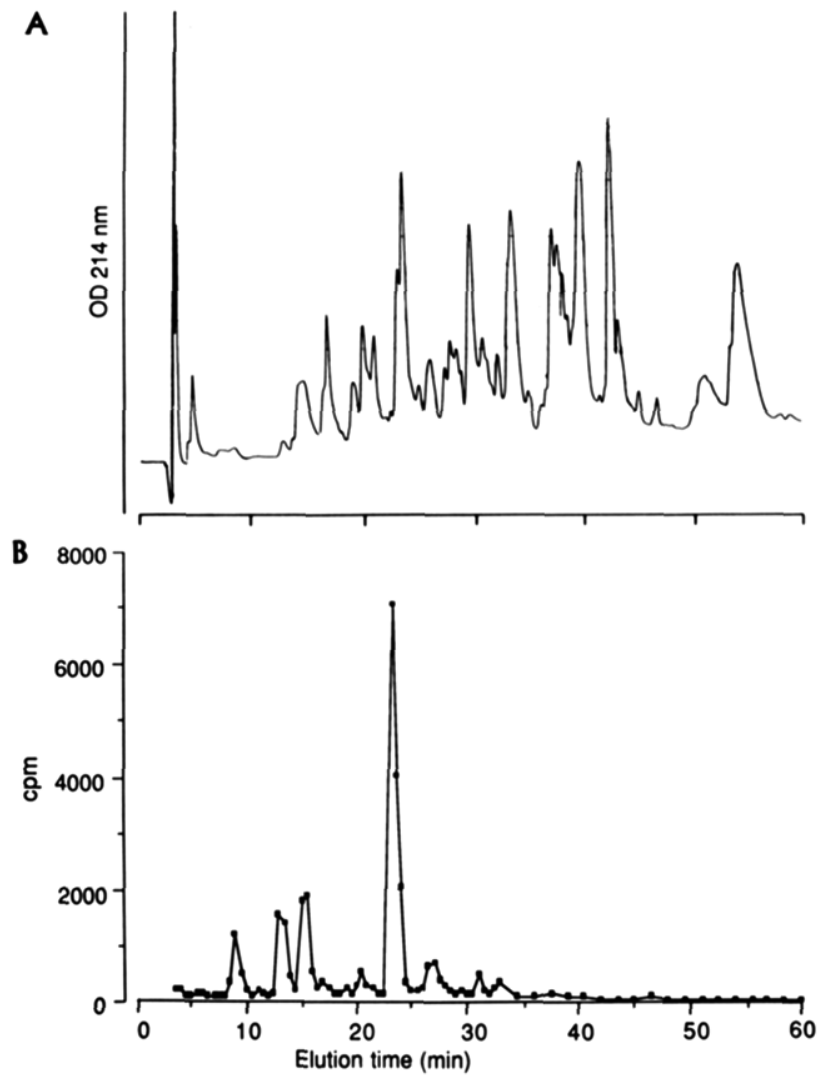

FIGURE 3: Sites of phosphorylation of $B P$ from myelin, $P_{3} A$, and $P_{3} B$. Myelin was phosphorylated as described under Materials and Methods. BP was isolated and digested with trypsin. Radioactive peptides were analyzed by reversed-phase HPLC using a linear gradient from $0.05 \%$ trifluoroacetic acid to $0.05 \%$ trifluoroacetic acid $/ 60 \%$ acetonitrile at a flow rate of $1 \mathrm{~mL} / \mathrm{min}$. Fractions of $0.5 \mathrm{~mL}$ were collected, and aliquots of $50 \mu \mathrm{L}$ were used to determine the amount of radioactivity. (A) Absorbance profile $(214 \mathrm{~nm})$ of a tryptic digest of BP isolated from myelin. (B) Radioactivity.

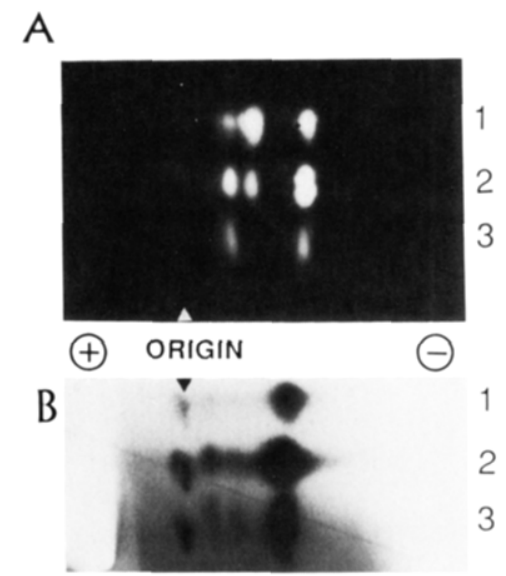

FIGURE 4: High-voltage electrophoresis of phosphopeptides in the major radioactive HPLC peak. The major radioactive HPLC peak from the tryptic digest of BP isolated from myelin was electrophoresed as described under Materials and Methods. (A) Fluorescamine staining of peptides. Lanes 1, 2, and 3 represent fractions of the major peak (23, 23.5, and $24 \mathrm{~min}$, respectively). (b) Autoradiogram showing phosphorylated peptides. Lanes $1-3$ as above.

with this peak, most of the radioactivity was associated with one of the peptides. The major peptide was eluted from the plate, and the amino acid composition was determined. This peptide was confirmed as peptide 98-105 which contains two possible sites of phosphorylation, i.e., Thr-98 and Ser-102, subsequently identified (see below).

The minor radioactive HPLC peaks were also further purified by high-voltage electrophoresis on thin-layer plates. The

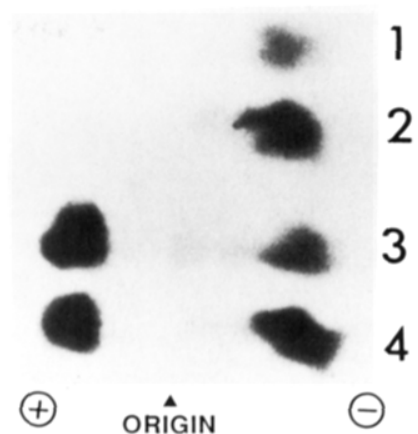

FIGURE 5: High-voltage electrophoresis of phosphopeptides in minor radioactive HPLC peaks. Minor radioactive HPLC peaks from the tryptic digest were electrophoresed on thin-layer plates as described under Materials and Methods. (Lanes 1 and 2) Fractions of peak (13.5-14 $\mathrm{min}$ ). (Lanes 3 and 4) Fractions of later peak (14.5-15 min).

peak which eluted with a retention time of 13.5-14.0 min contained one phosphorylated peptide, whereas the radioactive peak eluting at $15.0-15.5$ min separated into two phosphorylated peptides (Figure 5). Due to insufficient amounts of these minor phosphopeptides eluted from the thin-layer plate, confirmation of the assigned amino acid sequences was not possible at this time.

Comparison of the Sites of Phosphorylation of Basic Protein in Myelin and Myelin-Containing Fractions. The sites of phosphorylation of basic protein in myelin and myelincontaining fractions were compared by HPLC analysis of tryptic digests. Basic protein in myelin, $P_{3} A$ and $P_{3} B$, was phosphorylated as described under Materials and Methods. The basic protein from each fraction was isolated and digested with trypsin, and aliquots of the tryptic peptides containing the same amount of radioactivity were separated by reversed-phase HPLC. The elution of radioactive peptides from myelin $\mathrm{P}_{3} \mathrm{~A}$ and $\mathrm{P}_{3} \mathrm{~B}$ was identical. One major radioactive peak, eluting at $23 \mathrm{~min}$, was observed in the basic protein from all three fractions (chromatograms not shown).

The similarity of the radioactive profiles suggests that the phosphorylation occurred at one major site on basic protein in all myelin fractions. There were variable amounts of non-peptide ${ }^{32} \mathrm{P}$ eluted at $3.0 \mathrm{~min}$ (the void volume of the column) in the denser myelin fractions. Since it eluted with ATP, it was not examined further.

Isolation of Phosphorylated Amino Acid. Since peptide 98-105 contains both a Thr and a Ser residue, the peptide was hydrolyzed as described under Materials and Methods, and the phosphoamino acids were separated by electrophoresis on thin-layer plates. The data are shown in Figure 6. The phosphoserine standard was well separated from the phosphothreonine standard (Figure 6A). After exposure to X-ray film, a single radioactive spot was found which corresponded exactly to phosphoserine. We concluded that the major site phosphorylated on basic protein in vitro in the native membrane occurred on Ser-102.

\section{Discussion}

In the present investigation, we have shown a close correlation between the distribution of $\mathrm{Ca}^{2+}$-sensitive protein kinase activity, specific activity of phosphorylated basic protein, and differences in the basic protein microheterogeneity in human myelin-containing fractions. In agreement with other studies (Miyamoto \& Kakiuchi, 1974; Steck \& Appel, 1974; Sulhake et al., 1980), basic protein served as the major substrate for phosphorylation by an endogenous kinase in each of the fractions examined (data not shown), but it was more accessible in myelin with fewer lamellae, resulting in specific 


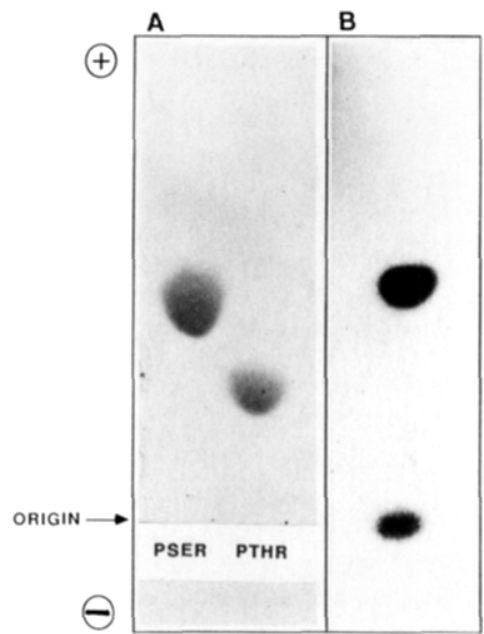

FIGURE 6: Phosphoamino acid analysis of the major radioactive HPLC peak. Electrophoresis of the major radioactive HPLC peak containing the acid hydrolysate of phosphopeptide 98-105 was carried out on thin-layer plates as described under Materials and Methods. (A) Positions of phosphoserine (PSER) and phosphothreonine (PTHR) standards as detected with ninhydrin staining. (B) Autoradiogram of thin-layer plate showing position of ${ }^{32} \mathrm{P}$-labeled phosphoserine from peptide 98-105.

activities of phosphorylated basic protein which were 2-3 times higher than that observed for basic protein from compact myelin.

Available evidence suggests that basic protein is inserted into all myelin membranes simultaneously following biosynthesis (Yang et al., 1987). In order to explain the increase in less cationic components of basic protein in the denser myelin (Cruz \& Moscarello, 1985), either these modifications occur on the completed membrane or specific combinations of basic protein isomers are synthesized and inserted into the specialized myelin membranes. In support of the latter, Fischer and Morrell (1974) have suggested that the metabolic stability of basic protein incorporated into the interior layers of the myelin sheath may be greater than on the peripheral lamellae.

Certainly, the rapid turnover of phosphate groups on basic protein (Desjardins \& Morell, 1983) coupled with the presence of protein kinases (Miyamoto \& Kakiuchi, 1974; Sulakhe et al., 1980; Martenson et al., 1983; Turner et al., 1984; Kishimoto et al., 1985; Chan et al., 1986) and phosphatases (Yang et al., 1987) in myelin would suggest a mechanism for rapid modification of basic protein exists in situ.

Ser-102, which follows immediately the triproline sequence (ThrProProProSer), is the major site phosphorylated in all fractions in the order of specific activities $P_{3} B>P_{3} A>$ compact myelin. Other posttranslational modifications which are known to occur at this site in the protein include glycosylation (Cruz \& Moscarello, 1983; Cruz et al., 1984) at both Thr-95 and Thr-98 in a sequential manner, at Thr-95 first, followed by Thr-98 (Persaud et al., 1988). Deamidation of the Gln residue at position 103 and methylation of Arg-107 have been reported also (Boggs et al., 1982). Therefore, in this short sequence of amino acids (Thr-95-Arg-107), at least five posttranslational modifications have been observed, permitting rapid modifications of MBP in keeping with its dynamic role in myelin.

In spite of the differences observed in the specific activities of basic protein from the different fractions and the levels of protein kinase activity, phosphorylation occurred at one major site and three minor sites in basic protein from all fractions. The preferred site of phosphorylation was identified as Ser-102, which is close to the major site identified in vivo (Thr-96) on rabbit myelin basic protein (Martenson et al., 1983). In an earlier study, peptide 98-105 of human MBP was shown to be phosphorylated in vivo (Chou et al., 1978); however, it was not established whether Thr-98 or Ser-102 was the residue phosphorylated. In vitro, a synthetic peptide corresponding to the sequence of residues $97-103$ is an excellent substrate for protein kinase C (Chan et al., 1986).

Although the role of phosphorylation of basic protein is still unknown, several reports have suggested that phosphorylation of basic protein has profound effects on the stability of the myelin sheath (Cheifetz \& Moscarello, 1985; Cheifetz et al., 1985). The less positively charged components were less effective in the formation of multilayers than the more positive isomers of basic protein (Brady et al., 1985; Moscarello et al., 1986). Phosphorylation of component 1 with exogenous protein kinase reduced its ability to interact with lipid vesicles (Cheifetz \& Moscarello, 1985). In addition, basic protein isolated from the compact, multilamellar myelin was more effective in aggregating lipid vesicles than basic protein from denser myelin (Cruz \& Moscarello, 1985). All of these studies support the idea that phosphorylation of basic protein, rendering it less cationic, destabilizes the structure of the myelin sheath by altering the compactness of the apposed cytoplasmic sides of the bilayers. Whether these local changes in myelin structure play important roles in the maintenance and metabolism of myelin remains to be determined. In this respect, it is interesting that the looser myelin fractions were found to be markedly reduced compared to the compact fractions from white matter of victims of multiple sclerosis (Moscarello et al., 1986). Perhaps the local perturbations in membrane structure that are proposed to occur in less compact myelin expose new antigenic sites on basic protein, making it more susceptible to breakdown in diseased brain by antibodies against MBP.

Registry No. Protein kinase, 9026-43-1.

\section{REFERENCES}

Benjamins, J. A., Gray, M., \& Morell, P. (1976) J. Neurochem. 27, 571-575.

Boggs, J. M., Moscarello, M. A., \& Papahadjopoulos, D. (1982) in Lipid-Protein Interactions (Jost, P., \& Griffith, O. H., Eds.) Vol. 2, pp 1-52, Academic, New York.

Brady, G. W., Fein, D. B., Wood, D. D., \& Moscarello, M. A. (1985) Biochem. Biophys. Res. Commun. 126, 1161-1165.

Chan, K.-F. J., Stoner, G. L., Hashim, G. A., \& Huang, K.-P. (1986) Biochem. Biophys. Res. Commun. 134, 1388-1364.

Cheifetz, S., \& Moscarello, M. A. (1985) Biochemistry 24, 1909-1914.

Cheifetz, S., Moscarello, M. A., \& Deber, C. M. (1984) Arch. Biochem. Biophys. 233, 151-160.

Cheifetz, S., Boggs, J. M., \& Moscarello, M. A. (1985) Biochemistry 24, 5170-5175.

Chou, F. C.-H., Chou, C.-H. J., Shapiro, R., \& Kibler, R. F. (1976) J. Biol. Chem. 251, 2671-2679.

Chou., C.-H., Chou, F. C.-H., Kowalski, T. J., Shapira, R., \& Kibler, R. F. (1978) J. Neurochem. 30, 745-750.

Cruz, T. F., \& Moscarello, M. A. (1983) Biochim. Biophys. Acta 760, 403-410.

Cruz, T. F., \& Moscarello, M. A. (1985) J. Neurochem. 44, 1411-1418.

Cruz, T. F., Wood, D. D., \& Moscarello, M. A. (1984) Biochem. J. 220, 849-855.

Deibler, G. E., Martenson, R. E., \& Kies, M. W. (1972) Prep. Biochem. 2, 139-165. 
Deibler, G. E., Martenson, R. E., Kramer, A. J., Kies, M., \& Miyamoto, E. (1975) J. Biol. Chem. 250, 7931-7938.

DesJardins, K. C., \& Morell, P. (1983) J. Cell Biol. 97, 438-446.

Fischer, G., \& Morell, P. (1974) Brain Res, 74, 51-65.

Golds, E. E., \& Braun, P. E. (1978) J. Biol. Chem. 253, 8171-8177.

Hunganir, R. L., Miles, K., \& Greengard, P. (1984) Proc. Natl. Acad. Sci. U.S.A. 871, 6968-6972.

Kishimoto, A., Nishiyama, K., Nakanishi, H., Uratsuzi, Y., Normura, H., Takeyana, Y., \& Nishizuka, Y. (1985) $J$. Biol. Chem. 260, 12492-12999.

Laemmli, U. K. (1970) Nature (London) 227, 680-685.

Lai, C. Y. (1977) Methods Enzymol. 47, 236-243.

Lowden, J. A., Moscarello, M. A., \& Morecki, R. (1966) Can. J. Biochem. 44, 567-577.

Martenson, R. E., Kramer, A. J., \& Deibler, G. E. (1975) J. Neurochem. 27, 1529-1531.

Martenson, R. E., Law, M. J., \& Deibler, G. E. (1983) J. Biol. Chem. 258, 930-937.

Matthieu, J. M., \& Waehneldt, T. V. (1978) Brain Res. 138, 29-43.
McIntyre, R. J., Quarles, R. H., Webster, H. De F., \& Brady, R. O. (1978) J. Neurochem 30, 991-1002.

Miyamoto, E., \& Kakiuchi, S. (1974) J. Biol. Chem. 299, 2769-2777.

Moscarello, M. A., Brady, G. W., Fein, D. B., Wood, D. D. \& Cruz, T. F. (1986) J. Neurosci. Res. 15, 87-99.

Murray, N. I., \& Steck, A. J. (1984) J. Neurochem. 43, 243-248.

Pereyra, P. M., Braun, P. E. (1983) J. Neurochem. 41, 957-973.

Persaud, R., Fraser, P., Wood, D. D., \& Moscarello, M. A. (1988) Biochim. Biophys. Acta (in press).

Peterson, G. L. (1977) Anal. Biochem. 83, 346-356.

Sulakke, P. V., Petrali, E. H., Davis, E. R., \& Thiessen, B. J. (1980) Biochemistry 19, 5363-5372.

Steck, A. J., \& Appel, S. H. (1974) J. Biol. Chem. 249, 5416-5420.

Turner, R. S., Kemp, B. E., Su, H., \& Kuo, J. F. (1984) J. Biol. Chem. 259, 11503-11507.

Yang, S.-O., Liu, J.-S., Fong, Y.-L., Yu, J.-S., \& Tzen, T.-C. (1987) J. Neurochem. 48, 160-166.

\title{
Stereoselectivity of the Guanyl-Exchangeable Nucleotide-Binding Site of Tubulin Probed by Guanosine 5'-O-(2-Thiotriphosphate) Diastereoisomers ${ }^{\dagger}$
}

\author{
Sukla Roychowdhury and Felicia Gaskin* \\ Oklahoma Medical Research Foundation, Oklahoma City, Oklahoma 73104 \\ Received December 21, 1987; Revised Manuscript Received June 7, 1988
}

\begin{abstract}
The active site of the exchangeable nucleotide-binding site of tubulin was studied by using diastereoisomers A $\left(S_{\mathrm{p}}\right)$ and $\mathrm{B}\left(R_{\mathrm{P}}\right)$ of guanosine $5^{\prime}-O$-(2-thiotriphosphate) (GTP $\beta \mathrm{S}$ ) where the phosphorus atom to which sulfur is attached is chiral. Turbidimetric measurements were used to follow kinetics, and electron microscopy was used to evaluate polymeric forms. Both isomers at $0.5 \mathrm{mM}$ promoted the assembly of tubulin in buffer containing $0.1 \mathrm{M} 2$-( $N$-morpholino)ethanesulfonic acid, $30 \%$ glycerol, $3 \mathrm{mM} \mathrm{MgCl}$, and $1 \mathrm{mM}$ EGTA, $\mathrm{pH} 6.6,23-37^{\circ} \mathrm{C}$. GTP $\beta$ S(A) promoted assembly into microtubules, although a few bundles were also found by electron microscopy. However, GTP $\beta S(B)$ induced assembly of tubulin into bundles of sheets and microtubules. As expected, $0.5 \mathrm{mM} \mathrm{GTP}$ induced tubulin to assemble into microtubules, thin sheets, and a few bundles. Both GTP and GTP $\beta S(A)$ were hydrolyzed in the tubulin polymers. However, more than $95 \%$ of the bound GTP $\beta$ S(B) was not hydrolyzed. Higher concentrations of GTP $\beta S(B)$, i.e., $1 \mathrm{mM}$, also induced bundles of sheets and microtubules, with $86 \%$ of the thionucleotide bound as the triphosphate. The GTP $\beta$ S(B)-induced polymers were considerably more cold stable than the GTB $\beta S$ (A)-induced microtubules, which were more cold stable than GTP-induced polymers. $\mathrm{Mg}$ (II) $(2-5 \mathrm{mM})$ had minimal effects on the structures induced by GTP $\beta S(A)$ or -(B) isomers in the tubulin assembly system. However, at $1 \mathrm{mM} \mathrm{Mg(II),} \mathrm{no} \mathrm{assembly} \mathrm{was} \mathrm{found} \mathrm{with} \mathrm{GTP} \beta S(A)$ and tubulin. The assembly studies on GTP $\beta$ S(A) and -(B) with microtubule protein (tubulin plus microtubule-associated proteins) showed similar kinetics at $0.5 \mathrm{mM} \mathrm{Mg}(\mathrm{II})$ in buffer without glycerol, and microtubules were the major structures. Most of the bound nucleotide was hydrolyzed. With varying $\mathrm{Mg}(\mathrm{II})$ and GTP or GTP $\beta$ S(B) concentrations, only microtubules were found. However, different $\mathrm{Mg}(\mathrm{II}) / \mathrm{GTP} \beta \mathrm{S}(\mathrm{A})$ ratios resulted in different polymeric forms with rings and cross-linked rings being the predominant polymers at high $\mathrm{Mg}(\mathrm{II})$ or GTP $\beta(\mathrm{A})$ concentrations. These studies demonstrate stereoselectivity at the $\beta$ phosphorus of the exchangeable nucleotide-binding site on tubulin. The GTP $\beta S(A)$ isomer is a better GTP analogue than GTP $\beta S(B)$ in the tubulin assembly system, whereas GTP $\beta$ S(B) is a better GTP analogue in the microtubule protein assembly system.
\end{abstract}

Tuser ubulin is a unique guanine-binding protein with one exchangeable and one nonexchangeable binding site (Weisenberg et al., 1968; Dustin, 1984). The nonexchangeable binding site

\footnotetext{
${ }^{\dagger}$ Supported by NS24489 from the National Institutes of Health.
}

contains tightly bound GTP, which is released only when the protein is denatured. GTP at the exchangeable site is needed for optimal assembly into microtubules and is hydrolyzed. There is still some question as to whether hydrolysis takes place simultaneously or after subunit addition (Carlier \& Pantaloni, 